What part do the cornea and the other refractive media play in cases of actively developing myopia? We know that the cornea and lens may have normal values in myopia, but did they have the same value before the onset of myopia?

It is unlikely that we shall solve the problem of myopia without intensive study in its breeding ground-the schools. The past refractive history of the child recently become myopic is still an unexplored field. Study for over a period of years of unselected children in the infants' schools, with their inevitable and unknown quota of ultimate myopes, will amply repay the labour, for school myopia remains to the key to the problem.

\title{
REFERENCES
}

Betsch.一Klin. Monatsbl.f. Augenheilk., Vol. LXXXII, p. 365, 1929.

Brown and Kronfeld.-Trans. XIII Internat. Ophthal. Congress, Vol. I, p. 87. 1929.

Scheerer.-Ber. 47 Verslg. dtsch. Ophthal. Ges. Heidelberg, p. 118, 1928.

Scheerer and Seitzer.-Klin. Monatsbl. f. Augenheilk., Vol. LXXXII, p. 511, 1929.

Schnabel and Herrnheisser.-Z. Heilk. ref. Nagel's Jahrsber., p. 436, 1895.

Sourasky (Sorsby).-Brit. Jl. of Ophthal., Vol. XII, p. 625, 1928.

Steiger.-Die Entstehung der sphärischen Refraktionen des Auges. Berlin, 1913.

Stone.-Jl. Exp. Zool., Vol. LV, p. 193, 1930.

Straub.-Arch.f. Augenheilk., Vol. XXVI, p. 336, 1893.

Szily, von.-Arch. f. Ophthal., Vol. CX, p. 183, 1922.

Tron.-Idem., Vol. CXXII, p. 1, 1929.

Idem., Vol. CXXVI, p. 454, 1931.

Vogt.-Ber. 44 Verslg. dtsch. Ophthal. Ges. Heidelberg, p. 67, 1924.

Klin. Monatsbl. f. Augenheilk., Vol. LXXII, p. 212, 1924.

\section{THE REFRACTION IN CASES OF CONGENITAL TORTICOLLIS ASSOCIATED WITH HEMIATROPHY OF THE FACE}

BY

\author{
ARNOLD SORSBy AND MaRCELli SHAW \\ LONDON
}

AMONG the numberless theories on myopia, the view has been advanced that the myopic eye is the expression of the architecture of the orbit. Stilling and his followers held that low orbits were associated with myopia and high orbits with hypermetropia. The immense literature that grew up on this anthropometric view of myopia led to negative or at the least inconclusive results. SchmidtRimpler held strongly that the orbit accommodates itself to the eye. In anisometropia the orbits were found to be of the same measurement on both sides-a fact that certainly does not lend any 
support to Stilling's views. An interesting - and as far as we know - unexplored contrast to the evidence from anisometropia is supplied by the state of refraction in congenital torticollis. Here the orbit on the affected side shares the under-development of the face.

During the past five years we have observed nine cases of congenital torticollis associated with definite hemiatrophy of the face. Not only was the affected side of the face grossly smaller than the other, but the diameters of the affected orbit were also smaller. Five of the cases had had operations for the torticollis. In only one was there marked difference in the refraction of the two eyes, so that it is justifiable to conclude that influences in the development of the orbit do not affect the state of refraction of the eye.

The following summary table brings out the salient features in our nine cases :

\begin{tabular}{|c|c|c|c|c|c|c|}
\hline \multirow{2}{*}{$\begin{array}{l}\text { Sex } \\
\text { M. }\end{array}$} & \multirow{2}{*}{$\begin{array}{c}\text { Age } \\
16\end{array}$} & \multirow{2}{*}{$\begin{array}{c}\text { Whether } \\
\text { operated } \\
\text { for } \\
\text { torticollis }\end{array}$} & \multicolumn{2}{|c|}{$\begin{array}{l}\text { Vision with } \\
\text { correction }\end{array}$} & \multicolumn{2}{|c|}{ Refraction } \\
\hline & & & $\begin{array}{l}\mathrm{R} \\
6 / 6\end{array}$ & $\begin{array}{l}\mathrm{L} . \\
6 / 6\end{array}$ & $+1.50^{\mathrm{R} .}+0.5 \downarrow$ & $\begin{array}{l}\text { L. } \\
+20\end{array}$ \\
\hline $\mathrm{F}$. & 5 & " & & & +1.5 & +20 \\
\hline M. & 12 & ", & $6 / 6$ & $6 / 9$ & $+3^{\circ} 0$ & $+2.00+0.5 \rightarrow$ \\
\hline M. & 8 & ", & $6 / 9$ & $6 / 9$ & +3.5 & +35 \\
\hline M. & 53 & 一 & $6 / 6$ & $6 / 5$ & $\begin{array}{r}+4^{\circ} 00+0.5 \\
120^{\circ}\end{array}$ & $\begin{array}{r}+2.50+0.5 \\
60^{\circ}\end{array}$ \\
\hline M. & 8 & - & $6 / 24$ & - & $\begin{array}{r}+35^{\circ}=+1^{\circ} 0 \\
120^{\circ}\end{array}$ & $+250+1^{\circ} 0 \checkmark$ \\
\hline $\mathrm{F}$. & 49 & Yes & $6 / 9$ & $6 / 9$ & $-1 \cdot 25 \smile-0^{\circ} 5 \downarrow$ & -0.5 \\
\hline M. & 9 & - & $6 / 60$ & $6 / 9$ & $-6^{\circ} 00-1^{\circ} 0 \rightarrow$ & +25 \\
\hline M. & 12 & - & $6 / 6$ & $6 / 6$ & +15 & $+1^{\circ} 25$ \\
\hline
\end{tabular}

To exclude the possibility of the comparatively equal total refraction of the two eyes being made up of unequal components, i.e., the eyes being in reality asymmetrical in spite of equal refraction, the radius of corneal curvature and corneal refraction were determined in the seventh case in the series (F., aged 49). These proved to be practically identical in the two eyes, both showing remarkably low readings. (Radius of curvature : right cornea, $9 \cdot 9 \mathrm{~mm}$.; left cornea, $10 \cdot 15 \mathrm{~mm}$. Corneal refraction : right, $34 \mathrm{D}$. ; left, $33 \cdot 25 \mathrm{D}$. 
The marked asymmetry of the skull and the markedly different shape of orbit is well shown by the accompanying reproduction of an X-ray taken from the same patient. In the original plate the

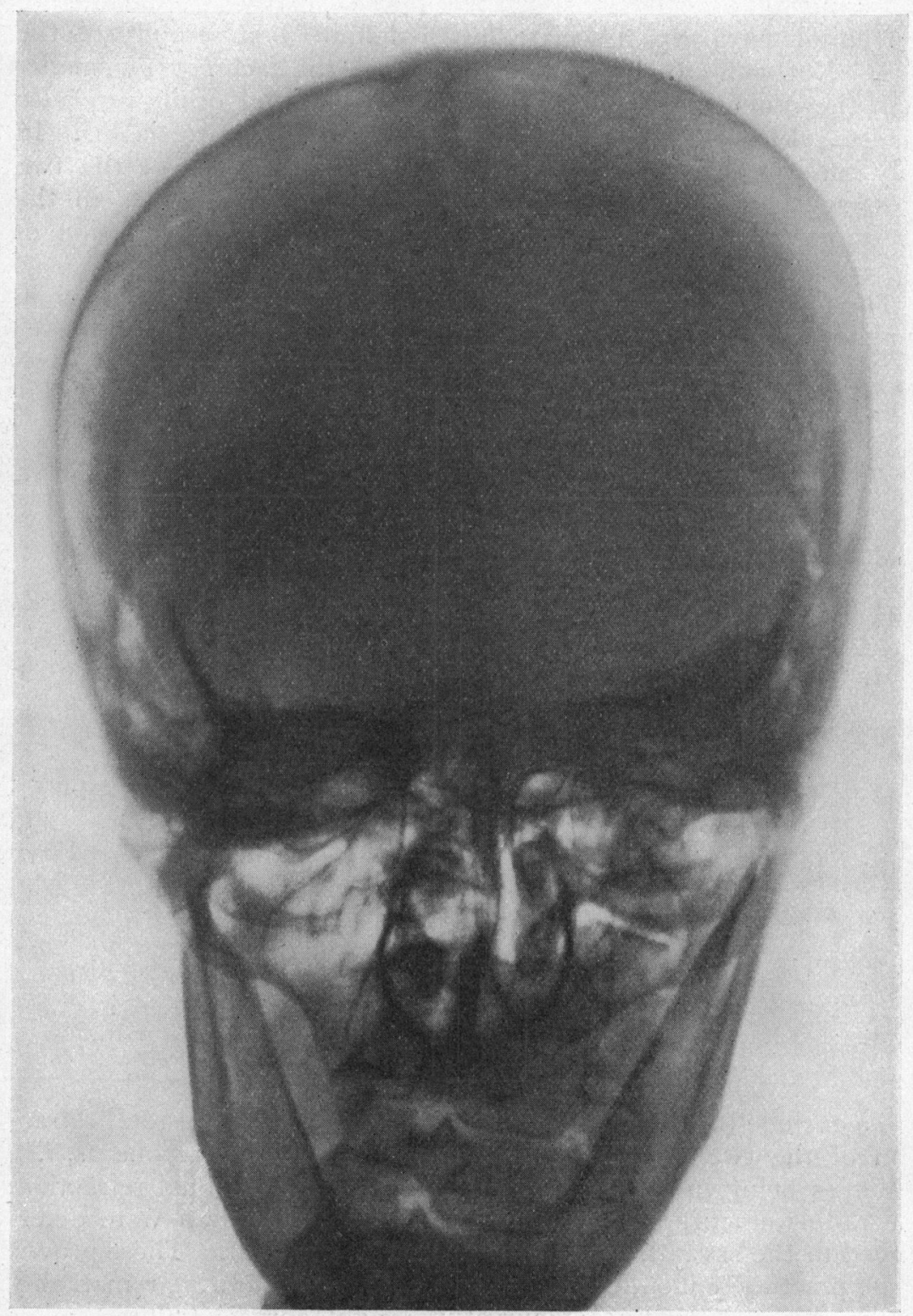

Case of Congenital Torticollis showing asymmetry of skull, including the orbits. 
largest vertical diameter of the right orbit is $4.6 \mathrm{~cm}$., that of the left $4.1 \mathrm{~cm}$.; the largest horizontal diameters are $4.1 \mathrm{~cm}$. and $3.9 \mathrm{~cm}$. respectively.

We wish to express our indebtedness to the surgical staffs of the Royal Eye Hospital and of Guy's Hospital for permission to follow up cases under their care.

\title{
A DEVICE FOR PREVENTING GLARE IN ELECTRIC OPHTHALMOSCOPES
}

BY

\author{
N. BISHOP HARMAN
}

\begin{abstract}
LONDON
THE introduction of the electric ophthalmoscope has greatly increased facilities for the examination of the interior of the eye, but the internal position of the source of the illumination within the instrument has produced certain new difficulties which the older reflecting ophthalmoscope did not possess. The electric lamp within the stem of the electric ophthalmoscope throws a beam of light parallel to the instrument, and this beam must be bent at right angles to enter the eye of the patient. Prisms and mirrors of various designs have been used to effect this bending. The desideratum is such a complete bending of the rays of light into the eye of the patient that the surgeon has a clear peep-hole through the instrument along the beam of light, and free from all disturbances such as will be caused by rays of light that may be diverted backward from the instrument so as to reach his own eye. If there are such aberrant rays the surgeon cannot see the fundus clearly by reason of the haze that is caused by the rays. The effect is somewhat similar to that disturbance to visibility produced by the rays of the head lamps of a car when there is a slight mist at night. These disturbing effects have become more evident with the increase in power of the light available.

The aberrant rays are brought about by several conditions. If a glass mirror with a drilled hole be used in the ophthalmoscope the beam of light will impinge upon the upper edge of this hole, and no matter how it may be blackened, this edge will scatter a blaze of disturbing light. If the mirror has no drilled hole but only a gap in the silvering, the hinder surface of the glass itself will reflect any light that may fall upon it from above the ophthalmoscope, and the slightest imperfection in the glass or dust upon it will increase the disturbance.
\end{abstract}

